\title{
Digital Debt Labour: Migration, Deportation and Offshoring in Mexico
}

\author{
Enda Brophy* and Rodrigo Finkelstein**
}

*Associate Professor, Simon Fraser University, Vancouver, Canada, ebrophy@sfu.ca

${ }^{* * P h D}$ Candidate, Simon Fraser University, Vancouver, Canada, rfindels@sfu.ca

\begin{abstract}
This article explores the convergence of debt, deportation, and digital labour in Mexico by describing the making of a labour force working on the frontlines of transnational debt collection, performing what we call digital debt labour. Drawing on dozens of interviews in Tijuana and Mexico City conducted between 2016 and 2019, we relate the growth of a debt collection labour force in Mexico. To theorise the intersection between debt, migration, and digital labour, this article explores three overlapping, converging, and expanding forms of migration: debt migration, or the circulation of consumer credit through markets for, or processes of, debt collection; virtual migration or the outsourcing of call centre work to offshore locations and the return migration of call centre workers in the labour process; and forced migration, or the deportation of undocumented migrants. Our core argument is that this case study demonstrates the manner in which a highly financialised and digital variant of capitalism is evolving to develop a multi-faceted and opportunistic relationship with the growing trends of migration and deportation.
\end{abstract}

Keywords: debt, financialization, financialisation, migration, virtual migration, deportation, digital labour, call centres

\section{Introduction}

It's mixed feeling. Mixed feelings because you feel for them [pause] because nevertheless they are going through hardship, medical hardship, and [...] you know, and you want to help them take care of their bills because you're on the end where you have the option to give them accommodations as far as taking care of their debt and whatnot [pause] But the mixed feelings come where, yeah, during debt, yeah, you're going through medical hardship, but you're not in Mexico, you know? So it's mixed feelings.

This article explores the growing convergence of consumer debt, digital labour outsourcing, and mass deportation in Tijuana, Mexico. In what follows we describe how these processes have combined to constitute a large and growing labour force of deportees working in Mexican call centres, a significant portion of whom perform what we call digital debt labour. This workforce of deportees - as illustrated by the opening quote above, offered by a worker who has been employed in offshored debt collection for nearly a decade - must collect from the indebted for fifty hours a week in a virtual labour process which confronts them with consumers in the United States (US), the very country that has expelled them or from which they have otherwise been forced to return.

The global context for digital labour offshoring has been changing rapidly since 2008 , as the post-Cold War neoliberal goal of a seamless global market, united by an equally planetary architecture of free trade agreements, has appeared increasingly 
tenuous in the face of populist movements, the resurgence of trade tariffs, and xenophobic pushes to reinforce and further militarise borders. Our study illuminates the manner in which cutting-edge sectors within digital capitalism (Schiller 1999) are realigning their operations in order to profit from what Mezzadra and Neilson (2013) refer to as the "productive power" of borders in an increasingly disciplinary global economic scenario.

The making of the digital debt labour force in Mexico is marked by diverse types of migration, including the initial migration of Mexican nationals northward in search of economic opportunity, the offshoring of consumer debt and associated debt collection contracts southward through digital networks, and the virtual migration (Aneesh 2006) of workers northward (again) across the US-Mexico border through the debt collection labour process in call centres. To better address the combination of processes fuelling the expansion of this specific form of digital labour, we describe three overlapping, converging, and expanding forms of migration within digital capitalism: debt migration, or the circulation of consumer credit through stages in, and markets for, debt collection; virtual migration, or the outsourcing of call centre work to offshore locations and the return migration of call centre workers in the labour process; and forced migration, or the mass-deportation of undocumented migrants from the US to Mexico.

Reflecting the affirmation of what William Robinson (2018) calls "accumulation by repression", the different moments of this workforce's constitution and labour process - debt migration, virtual migration, and forced migration - are united by a range of disciplinary or carceral logics, including criminalisation, detention, deportation, and, finally, submission to a panoptic workplace regime for a wage. In describing these forms of migration as united by a disciplinary continuum, we borrow from Michel Foucault's $(1995,236)$ genealogy of the prison-form, the ideal variant of which, according to prison reformers at the end of the 19th century, had "neither an exterior nor a gap" and was engaged in "unceasing" and "uninterrupted action" on the individual until its task - rehabilitation - was complete: an unceasing discipline. While in practice any power regime has its gaps (and this article's case study is no exception), the making of a debt collection labour force south of the US border relies on a series of punitive logics and associated redemptive discourses that accompany the forms of migration feeding into and characterising the virtual labour process we describe in this essay. While the end goal of debt collection is the securing of the realisation of surplus value, our case study illustrates how the 'soft' variants of subject formation operating within workplaces in regions at the economic centre (discourses of entrepreneurialism and passionate work, for example) are replaced or at the very least supplemented by more disciplinary methods of labour force formation and management at the periphery.

In what follows, we set the context for this inquiry by describing the parallel expansion of markets for consumer credit and the call centre industry in Mexico following the passage of the North American Free Trade Agreement (NAFTA) in the 1990s and, crucially, the financial crisis of 2008. Building on existing research exploring the formation of this deported workforce across Latin American countries such as Mexico, El Salvador, and Guatemala (Alarcón-Medina 2018; Anderson 2015; Da Cruz 2018; Goodfriend 2016; 2018; Meoño Artiga 2016), and drawing on 41 interviews in Tijuana and Mexico City conducted with debt collection workers, executives at debt collection companies, migrant rights activists, and industry observers between 2016 and 2019, 
we relate the rapid growth of call centres and an English-speaking deportee digital labour force in Mexico after the financial crisis. ${ }^{1}$

The specific focus of our research, however, is the growing subsection of those workers performing what we call digital debt labour, or collecting from afar on consumer debt in the US. Our study is important for several reasons. First, it contributes to a growing body of research by scholars exploring the role of migration in the making of class in digital capitalism (Aneesh 2006; Biao 2007; Huws 2014; Qiu 2010). Second, this study highlights the evolution of a transnational offshoring process in which American multinationals are increasingly opting for "nearshore" solutions for customer service following a racist backlash against Indian workers (Mirchandani 2012). Most importantly, our study reveals the manner in which a thoroughly financialised and debtdriven variant of capitalism is evolving to develop a multi-faceted and opportunistic relationship with the growing trends of migration and mass deportation, valorising the disciplining and expulsion of surplus populations and integrating shattered forms of proletarian identity into the labour process. Finally, we show how the overlap between repression, migration, and a highly informational labour process does not exhaust the resistant capacities of the new workforce, which, even as it experiences a highly abject condition, expresses a perpetual search for autonomy.

\section{Virtual Migration: Global Call Centre Capital and the Maquiladora}

The rise of the call centre sector in the last three decades offers a paradigmatic example of the differential forms of mobility marking digital capitalism. At the very apex of the transnational portion of the sector, what we have called global call centre capital (Brophy 2017) is highly mobile and cosmopolitan. Scholarly explorations of transnational call centre work during the first era of offshoring in the 2000s focused predominantly on the transfer of outsourced customer service work from the US and United Kingdom (UK) to India (Patel 2010; Poster 2007; Taylor and Bain 2008), but a cluster of firms at the pinnacle of the sector now operate in dozens of countries across the planet.

The most imposing example of the size and reach of these companies is Teleperformance, headquartered in France and employing 223,000 workers in 350 call centres across 76 countries. The only slightly more modestly sized Atento, owned by the financial investor Bain Capital, has over 154,000 employees scattered through 13 countries, including the US, Spain, and numerous Latin American states. Convergys, Sitel, Teletech, Sykes, and Accenture are among the leading American providers of call centre services, but the list of industry leaders also includes Wipro and Infosys from India all companies with annual revenues exceeding a billion USD.

${ }^{1}$ Research has unfolded across four yearly fieldwork sessions in Mexico (conducted in Mexico City in 2016 and in Tijuana in 2017, 2018, and 2019). Call centre and debt collection worker interviewees were initially contacted outside call centres in Mexico City and Tijuana. Interviews ranged from shorter interviews held on the street to, in later years of the project, hourplus semi-structured biographical interviews. Initial contacts provided access to new interviewees over the years. In addition to conducting interviews with new workers, yearly followup interviews have been conducted with a selection of the first workers contacted during the project, providing a longitudinal view of the changing conditions of employment within the industry. Of the 39 workers interviewed, 6 were female and 33 male, and all but two were Mexican nationals deported from the US, a sample which appears to roughly reflect the workforce composition of transnational debt collection call centres in Mexico. Secondary research on debt collection and ICT infrastructure in Latin America took place from 2016 to 2018 in Vancouver, Canada. 
Global call centre companies can arrive or pack up in the blink of an eye, alighting in new countries and buying out competitors depending on the opportunities available (most important among these are the presence of digital infrastructure, tax breaks, and workforces with the right mix of educational, linguistic, and cultural competencies) or closing their operations if conditions become less favourable.

By contrast, toiling within what the German labour activist collective Kolinko call "the sweatshops of the New Economy" (2002), the workforce which produces this borderless income for its employers enjoys no such freedom of movement. The outsourcing from the economic centre to the periphery which undergirds the development of this sector has provoked descriptions of call centres as an informational update of the maquiladoras that arose as part of the free trade agreements in the late 20th century (Mirchandani and Poster 2016, 20; Goodfriend 2016), with the key difference that the latter produce physical commodities whereas the former produce intangible services. Since any mobility transnational call centre workers have tends to be limited to the virtual dimension, one of the most influential theoretical contributions within the early scholarship investigating call centre labour outsourced to India was the concept of virtual migration, formulated by A. Aneesh (2006) to describe the labour process of Indian call centre workers and computer programmers.

As Carrillo Rowe et al. $(2013,2)$ indicate in their adoption of the term, virtual migration refers to the contradictory dynamic by which "in the call center industry the labour, not the body, is transported across national boundaries". Scholars of the emergent global call centre workforce have shown how virtual migration, often enacted in circumstances where the identity and the location of the call centre worker remains concealed, produces a unique set of cultural and subjective dislocations among the labour forces submitted to it, as Moroccan workers tele-commute to France and pretend to be French, Argentinian workers speak to consumers in Spain and pretend to be Spanish, and so on. This virtual movement of workers back and forth across borders and the resulting scrambling of cultural coordinates, as post-colonial scholars of the call centre have noted, "reconfigures the parameters of migration" and produces "an emerging form of mediated transnational labour" (Carrillo Rowe et al. 2013, 70).

\section{Debt Migration: The Debtor as Data}

The process of financialisation characterising the economy since the 1970s has brought with it, as a necessary correlate, growing levels of indebtedness. We define the variety of debt discussed in this article - consumer, or household debt - as that which is extended to workers in order to purchase means of subsistence, a form of debt which confronts money capitalists on the one hand and wage-labourers as consumers on the other. Here we offer a synthetic overview of the production, circulation, exchange, and collection of consumer debt in digital capitalism, paying particular attention to the representation of the debtor as digital data and the migration of this data through markets for, or processes of, debt collection.

We summarise this process as debt migration, or the movement of debt across firms and through the collection process in a tortuous quest to realise itself as profit. As Marx (1991) notes, debt only realises itself as profit at the end of its cycle, when it is paid with interest to finance capitalists. Before its transformation into profit, debt is nothing more than fictitious capital (1991), and one of capital's constant concerns is to ensure debt is 'repatriated' so that the accumulation cycle can begin once more. As Marx notes, "an accumulation of money capital means for the most part nothing more than an accumulation of these claims to production, and an accumulation of the market price of these claims, of their illusory capital value" (1991, 599). As he puts it, "It should 
not be forgotten here that this capital's money value, as represented by these papers in the banker's safe, is completely fictitious" (600).

The migration of debt through the collection process includes movement across three actors: collection departments, collection agencies and debt purchasers. Debt can circulate extensively among the three actors or intensively through debt collection processes at just one of them, and this movement continues until the debt realises itself as profit or is written off as surrendered surplus value.

Since the 1970s the growing influence of financial actors and logics, paired with the dissolution of welfare state supports, have produced the economy's structural reliance on consumer credit. The shift toward what scholars have called "debtfare" (Marazzi 2011; Soederberg 2014) has allowed capitalism to contain some of the contradictions associated with the crisis of social reproduction generated by neoliberalism (LeBaron and Roberts 2012). At the same time, the economy's structural reliance on consumer debt to guarantee the basic necessities of life for an underpaid, precariously employed, or underemployed workforce generates systemic vulnerabilities for the economic system more broadly.

The expansion of debt into a "general and permanent condition" (Ross 2014, 32) is illustrated in Canada, where by 2019 household debt hovered at a record-breaking 179 percent of disposable income (Canadian Press 2019), up from about 100 percent two decades ago (Poloz 2018). In the US, according to a recent report, household debt is now 869 billion USD higher than it was in 2008, with delinquency rates for credit cards and auto loans rising, and nearly $10 \%$ of student loans at least 90 days overdue (Federal Reserve Bank of New York 2019. As of 2017 one out of three Americans was estimated to have debt in collection (Ingraham 2017).

While indebtedness is an increasingly common condition, its inbuilt inequities along the intersections of class, race, and gender are a crucial part of the story. These include growing "unbanked" populations of the poorest consumers who cannot access service by established banks and are thereby thrust into the arms of more expensive lenders (Baradaran 2015). The proliferation since the 1980s of payday lending stores charging extortionate rates, especially in working-class communities of colour, is the clearest marker of the racialised distribution of opportunity built into debtfare, the most glaring example of which was the predatory lending that characterised the sub-prime mortgage frenzy of the 2000s (Joseph 2014). These trends highlight the manner in which capitalism, as Cedric Robinson (1983/2000) suggested, is always already a racialised mode of exploitation and domination, an insight to which we return in the last section.

The digital infrastructure upon which the credit system now depends was constructed alongside the rise of neoliberalism. With the US dollar unmoored from gold in the 1970s and money increasingly dematerialised in digital form, today the circuits of finance, through which debt and debtor data circulate, are those of information technology and vice versa (Schiller 2014). Josh Lauer's history of the credit reporting industry in America underscores how the invention of a "disembodied financial identity" $(2017,302)$ for consumers was central to tracking and rating debt, beginning in the 19 th century. As capitalism went digital in the late 20th century so too did the accounting, sorting, and assessment of debt, a process reliant on "binding financial and other data to individuals through space and time as they traverse networks, engage in interactions with various institutions, and especially accumulate assets and debts" (Gates 2010, 420).

When debt goes unpaid, the cycle of debt migration begins to unfold. Some companies have internal departments to track down balances owing by customers. Here, debt migrates internally through the company's collection department. Ownership is 
retained and no commission is paid on the settling of accounts. Other consumer debt is sold as a commodity on the debt sale market, which exploded in the 1990s. In this process, consumer debt is sold for pennies on the dollar to a debt purchaser. Within this movement, debt migrates externally - debt ownership is transferred and some debt may even be bought and sold multiple times until it is realised or written off. A third movement - which accounts almost entirely for the rise of the sector in Tijuana - is that the creditor retains ownership of the debt but outsources its collection, paying for the labour of debt collection agents and a commission upon recovery. In this case, companies which regularly collect debt from their customers will set up in the office of an established debt collection company - sometimes across a border.

As the author of the classic study Making People Pay Paul Rock $(1973,4-5)$ observed, debt collection "cultivates low visibility and is organized in a way that precludes public interest and awareness". The opaque nature of debt collection has remained a constant since Rock's study, and relatively little research is available on the industry and its labour processes. That which exists has underscored how debt collection is increasingly conducted at a distance, and that digital technologies are critical to its success (Deville 2015; Poster 2013). Email has all but replaced the physical letter, and the collections process has been more thoroughly rationalised since the 1970s as the sector has embraced the call centre. By the 2000s debt collection agencies were increasingly taking over the job from collection departments within firms due to the emergence of, and challenges associated with, "persistent debtors" (Burton 2008). Deville's (2012) study in the UK confirms the increasing incidence of default since the financial crisis and thus the growing importance to creditors of the collections industry and its rationalised methods.

As debt moves externally from a collection department to a collection agency it lives a data-intensive existence, compiled and managed through interlinked databases of credit reference and other forms of information about debtors. Deville's research shows how consumer debt flows through the agency, moving from team to team as it approaches legal action or being written off. The compilation and management of data warehouses storing "credit reference data, lifestyle and geo-demographic data, and 'closed user group' data” (Credit Management Research Centre 2008, 91) has been facilitated by advances in computer technology and software. Debt collection companies increasingly utilise algorithmic methods to segment debtors, grouping them by knowledge about their past actions, and sorting them via econometric scoring and external datasets (Deville 2012). As one industry observer suggests, "every piece of data is vital - so the credit inquiries, charged-off accounts, address history, name variations all mean something and are invaluable tools" (quoted in Detweiler 2014). This is especially the case for debt that is resold to a debt purchaser, since, as outlined by an insider in one exposé of the US debt market, "It is just data you are purchasing" (quoted in Halpern 2014).

Rock (1973) also described the debt collector as having an enforcement role in a disciplinary continuum that can include court appearances and incarceration in the effort to ensure the realisation of surplus value is secured. The resurgence of debtor's prisons in the US, a key grievance in the 2016 Ferguson uprisings (Sobol 2016), can be seen as part of a broader trend toward "the coercive governance of the social insecurity generated by neoliberal social and economic policies" (LeBaron and Roberts 2012 , 26), or what Jackie Wang (2018) simply calls "carceral capitalism," a formation in which the connection between debt and discipline is central to capital accumulation (Mahmud 2012). 


\section{Forced Migration: Call Centre Nearshoring and Mass Deportation in Mexico}

The 1994 signing of NAFTA, which opened up strategic economic sectors in Mexico for foreign competition and investment, constituted a parting of the waters as far as the establishment of the call centre sector in that country is concerned. NAFTA was enacted against the backdrop of a weak Mexican economy, marked by high interest rates, soaring inflation, and fading purchasing power (Micheli 2012). Among the sectors liberalised under the trade agreement were finance, consumer credit, and telecommunications. In Mexico, as elsewhere, the banking sector used call centres to offer and service credit cards, insurance companies used call centres to offer insurance coverage, and telecommunication companies used call centres to offer and support mobile and Internet services. This trend resulted in the rapid domestic growth of call centres during the 1990s in the metropolitan areas of Mexico City, Guadalajara, Monterrey, and Tijuana, with US-based Teletech and the Mexican company Tecmarketing (owned by Telefonos de Mexico) emerging as early market leaders for transnational and domestic call centre services respectively (Hualde and Micheli 2016).

Whereas companies' domestic outsourcing of customer service functions determined the rise of call centres such as Tecmarketing in the 1990s, offshoring - the outsourcing of such functions across borders - became pervasive during the 2000s. The transnational segment of the call centre industry in Mexico expanded significantly during this time, taking off after the financial crisis of 2008. The main global players Teletech, Teleperformance, SITEL, and Atento - are all located in Mexico, and by 2010 the number of call centres providing services to external markets had reportedly increased to 18,701, a 116\% spike in three years (Micheli 2012). In 2013, the International Labour Organization, citing the Mexican Institute of Teleservices, estimated that the number of call centre positions in Mexico stood at 575,000. Al Jazeera reports that the size of the market is worth 6 billion USD (Wessler 2014).

The growth of the transnational call centre sector in Mexico should be seen in the context of a broader "dispersal" of call centre operations across the globe since 2008 (Mirchandani and Poster 2016), but one development in particular has been critical to the sector's recent growth: Mexico has benefited substantially from a nationalist and racist backlash in the US against the offshoring of call centre work in the 2000s to India (Mirchandani 2012). By contrast to India and the Philippines, as a 'nearshore'solution for US call centre operations, Mexico is in the same time zones and can offer a workforce that requires no cultural training or the production of a "neutral accent" (Aneesh 2015). The country has therefore become an attractive option for American companies stung by an increasingly xenophobic mood among legislators, consumers, and the mainstream media.

By the late 2000s, recruitment of English-speaking workers had become fierce in the key Mexican cities. Until that point call centre employers had tended to follow the international trend of depending on a relatively young, majority female workforce with a university education and English proficiency, but this population on its own was not remotely sufficient in numbers to sustain the kind of growth the transnational call centre sector has experienced over the last decade.

As it happened, during the 2000s a growing wave of workers was moving southward, as decades of migration northward to the US was reversed by a steady flow of deportations to Mexico and other Latin American countries, inaugurating the process of forced migration. The US operates the world's largest immigration detention and deportation system, where on any given day some 30,000 people are held in administrative immigration detention (Global Detention Project 2019). Detentions and deportations of undocumented workers reached record levels in the years of Barack 
Obama's presidency, when according to one legal scholar detaining immigrants became "the largest mass incarceration movement in U.S. history" (Sinha 2015). The numbers underlying this phenomenon are stark. Immigration arrests in the US doubled from around 10,000 people in 1994 to 20,000 in 1998 (under Bill Clinton's presidency), then doubled again from 1998 to 2006 (under the last two years of Clinton and then under the George W. Bush administration), and then doubled again in the eight years following that (under the last two years of Bush and then the Obama administration), with somewhere around 100,000 people detained in a single year in 2013 (United States Department of Justice 2017, 5). While the trend has been for each American president over the last quarter-century to increase the deportation numbers, it was Obama, therefore, who left his successor "the most sophisticated and well-oiled human-expulsion machine in the history of the country" (Franco and Garcia 2016).

Donald Trump has pushed this inherited infrastructure of detention to its limits. In the first 100 days of the Trump administration, ICE claimed it arrested over 41,000 people, a 37\% increase over the previous year (United States Immigration and Customs Enforcement 2017). One of our interviewees suggested he was held in a county jail that was repurposed to hold detained migrants since nearby federal penitentiaries were full. The private-prison lobby, which profits from these arrests and incarcerations, estimates there will be a $450 \%$ increase in ICE-contracted detention resources, an expansion which will require more facilities to accommodate both individuals and entire families picked up in the growing number of raids completed under the auspices of the Department of Homeland Security (Alvarez 2017). Stock prices of for-profit prison operators like CoreCivic soared with Trump's victory in 2016 (Woodman 2017).

Once arrested, detention during deportation proceedings can last months or even years. Inadequate medical care, intimidation, physical and sexual assault by guards, malnourishment, forced labour, solitary confinement, separation of children from their parents and a spike of deaths in detention centres since Donald Trump's election have all been denounced by advocates and inmates in ICE-contracted penitentiaries. These abuses triggered a wave of hunger strikes by inmates in the states of California, Washington, and Georgia in 2017, a development which according to one journalist reflects "an epidemic of impunity and unrest in both public and private detention facilities" (Chen 2017).

The spillover effects of the mass deportation system that has been established in the US are being felt across Latin America, as the US and also, significantly, Mexico, deport migrants at an unprecedented rate. In 2015 alone Mexico deported 165,000 people to countries in Central America, while the US expelled 75,000 (Lakhani 2016). Many of these deportees simply try to return to Mexico and the US once more, adding themselves to the tide of migrants fleeing Guatemala, Nicaragua, or El Salvador, three of the world's most violent countries that to this day suffer the legacy of American military intervention during the Cold War. The result is a growing humanitarian crisis, as thousands of migrants are exposed to organised crime groups, people smugglers, or corrupt officials, on increasingly risky migration routes toward an ever-more elusive chance at safety and security.

\section{Discipline Put to Work: The Making of a Digital Debt Collection Workforce}

The trends of debt migration, forced migration, and virtual migration converged decisively in Mexico after the financial crisis. The San Ysidro border crossing between Tijuana and San Diego is the world's busiest, with 300,000 people using the connecting bridge every day. Tijuana is also Mexico's top deportation destination from the US, where one in five deportees are placed, often irrespective of whether they have an 
existing connection to the city (Lakhani 2017). Over 32,000 deportees were sent back through Tijuana in 2017 (Dibble 2018). An estimated third or more of these deportees remain in the city, often because they lack support networks in their places of origin or to remain as close as possible to family and friends in the US. ${ }^{2}$ The impact of this forced migration on Tijuana is impossible to ignore. "It's changed the face of the city," notes Pat Murphy (2018), a Scalabrinian priest at La Casa del Migrante, a migrant shelter on the hills overlooking the downtown area.

"In 1993, there was no such thing as deportees," Murphy explains, "it was everybody going north looking for another life". A quarter-century later, the migratory flow has been reversed entirely. Moreover, it is not just the direction of the migratory process that has changed but also the political and social conditions of such movement. Murphy divides the deportees arriving in Tijuana into two groups. The first is those who have been serving sentences in jail, who arrive in their prison sweats. Murphy notes that these deportees have had time to "make peace" with the prospect of being deported: "The longer they've been in jail, the more disciplined they are". Murphy notes that the second group, those who have been unexpectedly arrested at work or while driving under the influence, and then deported, are more of a challenge. These are the undocumented to whom deportation comes as a sudden shock, who may have lived in the US since they were children brought over the border by their parents and are now going through the wrenching process of leaving their loved ones behind.

Amid the trauma of detention and then expulsion, navigating life in Tijuana as a recent deportee is brutal. Once deported, migrants are barred from applying for a visa for ten years and faced with a three-year automatic jail term if they return illegally. Most lack basic documentation, not to mention the cultural cues of Mexican societies, and sometimes even the language. As one of our interviewees remarked, "I see some of the guys that come down here, they get deported with absolutely no Spanish [laughs] and it's tough, man. It's tough." Deportees face racism from locals and are targeted by police, especially if they carry the outward signs of having had a criminal lifestyle in the US. Work is difficult to come by and, when found, barely covers the cost of life. Construction work and the maquiladoras are unappealing possibilities.

In a dramatic irony, the form of virtual migration at the heart of the high-surveillance production process in the call centres, a virtual movement of labour across borders, is often a deportee's best option to earn a living. In the Tijuana business district, ubiquitous posters with beaming young people on them promise, in English, 3000 pesos a week (roughly $\$ 160$ (US)) plus commissions once a certain threshold of debt is collected. At migrant shelters in Tijuana the same adverts for call centre employment can be found on bulletin boards, and computer literacy courses are now being offered as a means for deportees to find work. These developments point to the pipeline running freshly deported workers to a new niche of transnational call centre capital - smaller, independent companies whose business plan depends on putting deportees' language and culture to work along the digital assembly lines. In their continual search for fresh labour power, the main debt collection company in town even sends a van out to the San Ysidro crossing to hand out leaflets every Friday night when the deportees are dropped off, disoriented, into their new lives.

The convergence of virtual migration and forced migration is particularly robust in Tijuana. The websites of companies in the city betray the confluence of geopolitical processes that the smaller niche sector of transnational call centre capital depends on:

2 This estimate was provided by Pat Murphy (personal communication, April 26, 2018) based on studies conducted for the Casa del Migrante. 
"Need work along the border?" asks one Contact Center company on its "Now Hiring" page. Under the tab "Nearshore Debt Collection", another company points out that "Baja agents are typically 50\% less [sic] than their U.S. counterparts, well educated, computer savvy, motivated and culturally aligned to North America."

The first and largest transnational debt collection company was established in Tijuana just after 2008. The co-founder described his motivation for setting up shop south of the border given the diminishing margins on debt collection after the global financial system flatlined: "I need agents to collect and I can't afford them in San Diego". The company, whose workers comprise the largest portion of our interviewee sample, has locations in Mexico City and Tijuana and has grown to employ over 750 people collecting medical debt, credit cards, loans, and mortgages. It offers 'turnkey' services to companies in the US: offering workspace, hiring, training, and managing the workforce, and charging clients in the US from \$12-14 (US) per hour per agent. By the 2010s, according to some of the deportees we interviewed, employees began to take the first calls that were re-routed from the Philippines when customers demanded to speak to an "American".

\section{6. "They Have to Pay": The Digital Debt Collection Labour Process}

A decade after the financial crisis, numerous businesses in Tijuana have branched out into transnational debt collection, with at least four new entrants opening in Tijuana alone over the last few years. Considering that some companies will conduct debt collection in addition to providing services such as tech support, and that the sector tends to be discreet if not downright secretive regarding its contracts from the US, we can surmise that the real number of call centres collecting on debt from US consumers is higher. It's estimated that the debt collection sector in the city is worth 80 million dollars (CDN) a year, and employs around 2,000 people (Asociación de Call Centers de Tijuana 2019).

Language, communication, and cultural competency are the key sources of value in call centres. An executive at one of the debt collection companies describes their business model as "finding new talented people", and the construction of a mass deportation system in the US ensures that they find such talent in growing numbers. According to one interviewee who worked in a debt collection company's human resources department, the company gets 15 applications a day, hires about 40 workers a month, and sees turnover of $30 \%$ a year.

In a reversal of the usually feminised labour force of the call centre, employees doing debt collection in Tijuana have historically been male. This is because employers in the sector initially felt it was a tough job that was best done by men. Moreover, having had a criminal lifestyle pre-deportation is tolerated and even embraced by the companies that have opened in the last decade, where the prevalent perspective among management seems to have been that a workforce of model citizens won't get you very far in debt collection. This supports findings by other research on debt collection service work. The sociologist Arlie Hochschild (1983/2003) famously referred to debt collectors as the "heel" of capitalism's service workforce, arguing they put in emotional labour requiring them to be "nastier than natural". Winifred Poster has described them as "emotional hitmen" $(2013,206) .^{3}$

The job certainly allows deportees - often broken and traumatised by the experience - to assert themselves over the phone in a world where so much control has

${ }^{3}$ In a more recent twist, debt collections companies are also increasingly hiring women, with some of the call centres displaying a more mixed gender ratio. 
been removed from them. A once-gang-affiliated interviewee with tattoos on his face that we interviewed described the job as requiring him to "talk to people, make them understand," projecting an implied but palpable violence. Another noted that while customer service involved apologising to customers all the time, in debt collection he could be more assertive. "I don't like to say sorry," he explains, adding: "you have to be a little more strong on collections. They can tell you the story and you can feel sorry for them, but at the same you have to... they have to pay". Asked if there was any similarity between the requirements of his criminal lifestyle in the US and the job of collecting debt, another deportee summarised it in one word: "hustle".

This putting to work of what Rock (1973) called "controlled unpleasantness" has been the bread and butter of a collector's trade in Tijuana. Since greater consumer protections in the US were passed and the Consumer Financial Protection Bureau created as a part of the Dodd-Frank Act under Obama after 2008, the industry's labour process has been subject to new restrictions:

Because when I started working there, it was still a chaotic world of collections where you could still threaten the consumer into paying [pause] but shortly after that, maybe within the second year that I was working in the company, this entire collection world started changing [pause] So, at the same time, I had to reinvent myself as a collector, because now I couldn't have the same attitude as I had before. It was challenging as well. Now you have to keep earning those bonuses, but you have to do it with a little, you know, you can't be [pause] mean, for a lack of a better word, to the consumer.

Beyond the bravado displayed by some male deportees about their jobs, interviews with debt collection workers in Mexico reveal a labour process which is emotionally and physically grinding. What the job ads don't mention are the 50-hour work weeks, the hyper-surveillance by management, and the steady stream of abuse workers will receive. One employee described the job as: "Hang-ups [pause] It's horrible. People insult you, especially because they don't want to pay you". By US law, debt collection companies are allowed to call someone once an hour until the person picks up the phone, and companies are allowed to interact with a debtor once a day. Automated dialling technology allows companies to make calls ceaselessly, and a day's work involves making hundreds of calls to debtors. "No, [we call them] everywhere. We call them to their cell phones, we call them to their house, to their sisters' house, to their friends' house," one collector says.

The labour process occurs within a regime of strict information control. The use of "skiptrace", an in-house or third-party service providing actionable data on debtors, is key to debt collection operations (as it is to bounty hunters and repossession agents). As one employee describes it, "Skiptrace is basically a database where they put in the name of the person and they locate all the numbers related to that person. So, they download it to the person's account and that's the numbers we dial". While the information is trained at debtors in order to reach them from afar, the data management strategy is reminiscent of carceral work settings. Debt collection offices are paperless and electronic devices are not allowed. Information about debtors comes from the US but does not remain on servers in Mexico, since the data (still anachronistically referred to in the industry as 'paper') has resale value on the black market. 


\section{Debt, Redemption, and Autonomy Seeking in the Digital Maquiladora}

In his landmark genealogy of surveillance and punishment, Michel Foucault (1995, 242 ) muses that "[i]f [...] the work of the prison has an economic effect, it is by producing individuals mechanized according to the general norms of an industrialized society [...] The making of machine-men, but also proletarians". Our research in Mexico suggests a 21st-century update of this observation regarding the economic effect of the prison and its disciplinary logics. As we have seen, the making of a digital debt labour force in these and other locations across Latin America draws on a series of developments, virtually all of which can be positioned along a disciplinary continuum. Disciplinary and carceral logics are intrinsic to the confluence of the three forms of migration we identify in this article. In this sense, discipline is both a conditioned and conditioning social relation in this process of class formation. On the one hand, discipline is a distilled product of this highly volatile migratory mixture. On the other, it is a force that produces the migratory forms we have described. We conclude this article by briefly summarising these contributing factors before highlighting some of the ways in which this digital workforce is undercutting the formidable array of forces arrayed against it.

The remarkable expansion of household debt in the US has resulted in a market for debt migration, determining the need for a growing digital debt collection workforce whose work it is to ensure capital realises its (perennially uncertain) goal of securing surplus value. Forced migration, including the expropriation, detention, and expulsion of a population increasingly deemed to be surplus to requirements, as well as the putting to work of its cultural competencies in an expanding offshored debt collection call centre sector, completes the picture of the ways in which debt, discipline, and dispossession have combined to produce a growing digital workforce south of the US border. In Tijuana, most glaringly, but also in major urban centres across Mexico and central America, this "unceasing discipline" (Foucault 1995, 236) mobilises digital technologies in the harvesting of profit off once-surplus populations in a process Hillary Goodfriend (2018) insightfully calls "recycling" workers. The application of such discipline highlights not only the manner in which a more thoroughly financialised version of capitalism has retained its intrinsically racial character, but how Latinx populations are enmeshed in the global debt system. Deportees are quite literally paying for it along the digital assembly line in Mexico - in time, in severed social and family networks, and in diminished levels of pay.

Returning to Foucault's reflection, work in prisons has a directly economic effect under neoliberalism of course, since in the US prisons are a significant business and - in an example that presents a clear continuity with the focus of this article - a company called Telverde operates four call centres at a prison complex in Arizona servicing clients such as Cisco, Hitachi, and SAP. But the key take-home from this research is that the "work of the prison" $(1995,242)$ in the age of forced migration, among other effects, includes the production of a racialised digital labour force out of a series of cascading forms of discipline. These range from the fiscal discipline imposed by global finance on the Mexican state in the 1980s after the country's sovereign debt crisis (which resulted in the privatisation of the telecommunications network and the lowering of costs for business customers), to the discipline inflicted by the US state on migrants as a part of its construction of a mass-deportation infrastructure beginning in the 1990s, through the labour discipline utilised by the debt collection employer on the deporteeworker, to the affective discipline directed by the collector over the phone against the indebted. Our research on this case study, then, illuminates the critical relationship between debt, discipline, and the production of surplus value under neoliberalism. Moreover, despite the rhetoric of Donald Trump, this research shows how capital and 
its labour processes can still traverse borders with ease, a condition which has only been facilitated by the carceral production of a labour force which is trapped by political and economic circumstances that are beyond its control.

Given this scenario, it is perhaps not surprising that pervasive within debt collection call centres is a management-fostered narrative of redemption, according to which the business is giving workers a 'second chance' to make good after having made 'bad decisions' in life. For deportees, the story implies that hard work offers the opportunity to rebuild a life in Mexico and repay one's debt to the community they abandoned by migrating north. As the founder of Tijuana's largest debt collection company put it in an expansive moment: "[w]e're more in the business of changing people's lives". He continues:

Because the option that we have, aside from the manufacturing companies, we're a higher-paying job. Somebody that's lived in the US can actually live in Mexico on their own, have all benefits and have peace of mind. At the end of the day, we're serving a bigger purpose than just, you know, our clients. I think that we're also helping that people transition back into their own country, be successful in their own country, using their talents and abilities, you know, that their clients benefit from.

The narrative of rehabilitation, which dovetails nicely with the management's perspective that agents are "helping" the indebted get back on track, was repeated by workers in dozens of interviews.

However, as prevalent as the redemption narrative is in the industry, not everyone is buying it. Even among a workforce formed in the crucible of such an intensely disciplinary subjection, interviews reveal a set of practices James C. Scott (1990) once called infrapolitics, or tactics of resistance that tend to be invisible to power but which nonetheless test the boundaries of what is possible given the circumstances.

To begin with, many collectors will openly talk about their dislike for the work. One worker begins: "what I like about here is the good pay, and the good environment," then looks up with a smile, and then says "and then there's the job". Some collectors will tweak the management-sanctioned script and sympathise with debtors, describing the debt as extortionate and even revealing that they pursue the amount owing less aggressively when possible. One collector described always offering the biggest discount he could to debtors at the expense of his employer's bonus (and his own), despite being warned against it, because, as he says, "they're just people, man".

Others show a more seething distaste for the structural factors which have put them in their positions, including the expansion of the debt system itself. One conversation with a debt collector provoked a scathing critique of this system and a related mercenary approach toward employment in the industry. During a description of how US federal law allows for the charging of compound interest on charges associated with utilities bills once a debt is acquired, he said:

You know what is really sad? Sometimes we collect on utilities [pause] Yeah, I can understand, they got the last bill, but the last cycle of the bill of utilities light, trash or sewer - it was 120 dollars. He decided not to pay for one, between, let's say two years, three years. That 120-dollar bill ended up summing 500 dollars. Because the law allows the interest to be charged. How is that? Is that fair? So you tell me, you tell me. One of the answers is that: What choices do I have? I'm making a living. I'm just making a living. That's how cruel the system is [...] So the system is working you, so why not work it? Exactly. They take my 
life, so why not get paid. And I told my lady, 'I'm going to give that money back with interest.' All the years that I worked [in the US], that they took my money [...] I was paying taxes. So I decided I'm going to join back [to Mexico] and I'm going to get paid. I'm going to get my money back with interests [...] I'm not happy about it, but I just [pause] It opened my eyes to the system. How cruel the system is.

At a broader scale, the rapid growth of the call centre industry in Tijuana, and the debt collection sector within it, has meant that businesses are increasingly competing for experienced workers, and collectors have begun to quit their jobs in order to move to employers offering a better deal. One worker describes the turnover this creates:

Oh, it's a revolving door. It's a revolving door because of how many call centres there are now. So you have an agent come in and work, and if they don't like whatever they may not be comfortable with, well, they know there's a call centre around the corner [pause] which literally there is! [laughs]

Wages have begun to rise and workers have been much more willing in recent years to share a counter-analysis of labour relations. One describes the times that executives from client companies travel to Tijuana and visit the call centre:

Sometimes I see all these [pause] like, a group of white men. Just these white men, nicely dressed, wealthy. Just the guys like off a fucking Just for Men or Rogaine commercial. Just like that, you know? Like four or five of 'em come in, and you see one of the head guys [pause] and you see them looking around the place. It's like they're walking, like they're going through like a zoo and we're just there working. And they're just like 'Look what we got here going on.' You know, like, you just got [pause] I feel like I'm better than this but for a second you would think maybe you're a fucking piece of cattle or something. Just like livestock: 'This is our livestock.' This is what's cha-cha-cha-ching!

A cornerstone of the dissident perspective workers put forward is the vindication of their labour's value. After working conditions, pay is the complaint heard most often from this workforce. When asked what the worst part of the job is one collector says: "I hate the fact that I work my ass off and they pay me like shit". Another who is forced to live separated from four children in the US displays a withering take on the redemption narrative: "They're not doing us a favour. They're not giving us a new life. We're making a lot of money and they don't want to pay for it". The process of labour arbitrage that underlies the industry is mentioned regularly: "Yeah, they do take advantage of it because they are going to pay you a lot less for some job [in the US] they would pay maybe triple. So in that sense, yeah, they're taking advantage of a lot of us". Having been in the industry many years, one collector we interviewed at length on several occasions keeps track of the money he recovers every week, as well as how small a commission he gets compares to the money which flows to his bosses and back north across the border. In a prolonged discussion he told us a story of the time he and his coworkers were on their break outside work and the boss drove by in his truck:

"Look," he said to the others, "Who do you think is paying for that [truck]? We're paying for that. We get the money." 


\section{References}

Alarcón-Medina, Rafael. 2018. Informational Returnees: Deportation, Digital Media, and the Making of a Transnational Cybertariat in the Mexican Call Center Industry. Dialectical Anthropology 42 (3): 42-293. https://doi.org/10.1007/s10624-018-9518-5

Alvarez, Priscilla. 2017. What the Spike in Immigration Arrests Might Mean for Detention Centers. The Atlantic, May 20, 2017. Accessed February 17, 2020. https://www.theatlantic.com/politics/archive/2017/05/ice-arrests-increase-nearly-forty-percent/527427/

Anderson, Jill. 2015. "Tagged as a Criminal": Narratives of Deportation and Return Migration in a Mexico City Call Center. Latino Studies 13 (1): 8-27.

Aneesh, A. 2015. Neutral Accent: How Language, Labor and Life Become Global. Durham, NC: Duke University Press.

Aneesh, A. 2006. Virtual Migration: The Programming of Globalization. Durham, NC: Duke University Press.

Asociación de Call Centers de Tijuana. 2019. Personal communication, July 24.

Baradaran, Mehrsa. 2015. How The Other Half Banks. Cambridge, MA: Harvard University Press.

Biao, Xian. 2007. Global Body Shopping: An Indian Labor System in the Information Technology Industry. Princeton: Princeton University Press.

Brophy, Enda. 2017. Language Put to Work: The Making of the Global Call Centre Workforce. New York: Palgrave.

Burton, Dawn. 2008. Credit and Consumer Society. London: Routledge.

Canadian Press. 2019. Statistics Canada says Household Debt Grew Faster than Income in Fourth-Quarter. Canadian Broadcasting Corporation, March 14, 2019. Accessed February 17, 2020. https://www.cbc.ca/news/business/household-debt-income-1.5056159

Carrillo Rowe, Aimee, Kimberlee Perez and Sheena Malhotra. 2013. Answer the Call: Virtual Migration in Indian Call Centers. Minneapolis: University of Minnesota Press.

Chen, Michelle. 2017. What Happens to Undocumented Immigrants Once They Fall Into ICE's Hands? The Nation, February 20, 2017. Accessed February 17, 2020. https://www.thenation.com/article/what-happens-to-undocumented-immigrants-once-theyfall-into-ices-hands/

Credit Management Research Centre (CMRC). 2008. Credit and Debt Management Survey 2008. Accessed March 5, 2018. http://www.cmrc.co.uk

Da Cruz, Michaël. 2018. Offshore Migrant Workers: Return Migrants in Mexico's EnglishSpeaking Call Centers. RSF: The Russell Sage Foundation Journal of the Social Sciences 4 (1): 39-57. https://doi.org/10.7758/RSF.2018.4.1.03

De Genova, Nicholas. 2013. The Legal Production of Mexican/Migrant "Illegality". In Governing Immigration Through Crime: A Reader, edited by Julie Dowling and Jonathan Inda, 4158. Stanford: Stanford University Press.

Detweiler, Gerri. 2014. Why You Can't Hide From Debt Collectors. ABC News, March 23, 2014. Accessed February 17, 2020. https://abcnews.go.com/Business/hide-debt-collectors/story?id=23011597

Deville. Joe. 2015. Lived Economies of Default: Consumer Credit, Debt Collection and the Capture of Affect. London: Routledge.

Deville, Joe. 2012. Regenerating Market Attachments. Journal of Cultural Economy 5 (4): 423-439.

Dibble, Sandra. 2018. Deportees Learn Workforce and Life Skills at Tijuana Migrant Shelter. San Diego Union Tribune, July 6. Accessed February 17, 2020. https://www.sandiegouniontribune.com/news/border-baja-california/sd-me-tijuana-deportees-20180706-story.html

Federal Reserve Bank of New York. 2019. Household Debt and Credit Report (Q4 2019). Federal Reserve Bank of New York Research and Statistics Group. Accessed 27 February, 2020. https://www.newyorkfed.org/microeconomics/hhdc.html.

Foucault, Michel. 1995. Discipline and Punish: The Birth of the Prison. New York: Vintage Books. 
Franco, Marisa and Carlos Garcia. 2016. The Deportation Machine Obama Built for President Trump. The Nation, June 27. Accessed February 17, 2020. https://www.thenation.com/article/the-deportation-machine-obama-built-for-president-trump/

Gates, Kelly. 2010. The Securitization of Financial Identity and the Expansion of the Consumer Credit Industry. Cultural Studies 34 (4): 417-431.

Global Detention Project. 2019. United States Immigration Detention. Accessed July 16. Accessed February 17, 2020. https://www.globaldetentionproject.org/countries/americas/united-states

Goodfriend, Hilary. 2018. Deportation as Outsourcing in El Salvador's Call Center Industry, Viewpoint Magazine, February 1. Accessed February 17, 2020. https://www.viewpointmag.com/2018/02/01/deportation-outsourcing-el-salvadors-call-center-industry/

Goodfriend, Hilary. 2016. Deportation Profits: El Salvador's Call-Center Industry is Profiting off US Deportees. Jacobin, December 16. Accessed February 17, 2020. https://www.jacobinmag.com/2016/12/migration-deportation-outsourcing-undocumented-el-salvador/

Halpern, Jake. 2014. Inside the Dark, Lucrative World of Consumer Debt Collection. The New York Times, August 14. Accessed February 17, 2020. https://www.nytimes.com/interactive/2014/08/15/magazine/bad-paper-debt-collector.html

Hochschild, Arlie Russell. 1983/2003. The Managed Heart: Commercialization of Human Feeling. Berkeley: University of California Press.

Hualde, Alfredo and Jordi Micheli. 2016. The Evolution of Call Centres and the Implication for Service Quality and Workforce Management in Mexico. In Innovation and Internationalization of Latin American Services, edited by René Hernández, Alfredo Hualde, Nanno Mulder, and Pierre Sauvé, 177-194. Santiago: ONU-ECLAC/El Colegio de la Frontera Norte.

Huws. 2014. Labor in the Global Digital Economy: The Cybertariat Comes of Age. New York: Monthly Review Press.

Ingraham, Christopher. 2017. Americans are drowning in debt. Here's where they have it the worst. The Washington Post, December 8. Accessed February 17, 2020. https://www.washingtonpost.com/news/wonk/wp/2017/12/08/americans-are-drowning-indebt-heres-where-they-have-it-the-worst/?noredirect=on\&utm term=.960149b8ed5d

Joseph, Miranda. 2014. Debt to Society: Accounting for Life under Capitalism. Minneapolis: University of Minnesota Press.

Kolinko. 2002. Hotlines: Call Centre, Inquiry, Communism. [web publication]. Accessed February 17, 2020. http://www.nadir.org/nadir/initiativ/kolinko/lebuk/e lebuk.htm

Lakhani, Nina. 2017. This is What the Hours After Being Deported Look Like. The Guardian, December 12. Accessed February 17, 2020. https://www.theguardian.com/inequality/2017/dec/12/mexico-deportation-tijuana-trump-border

Lakhani, Nina. 2016. US and Mexico's Mass Deportations Have Fueled Humanitarian Crisis, Report Says. The Guardian, July 27. Accessed February 17, 2020. https://www.theguardian.com/world/2016/jul/27/us-mexico-mass-deportations-refugees-central-america

Lauer, Josh. 2017. Creditworthy: A History of Consumer Surveillance and Financial Identity in America. New York: Columbia University Press.

LeBaron, Genevieve, and Adrienne Roberts. 2012. Confining Social Insecurity: Neoliberalism and the Rise of the 21st Century Debtors' Prison. Politics \& Gender 8 (1): 25-49.

Mahmud, Tayyab. 2012. Debt and Discipline. American Quarterly 64 (3): 469-494. https://doi.org/10.1353/aq.2012.0027

Marazzi, Christian. 2011. The Violence of Financial Capitalism. Los Angeles: Semiotext(e).

Marx, Karl. 1991. Capital Volume III. London: Penguin Classics.

McNally, David. 2011. Global Slump: The Economics and Politics of Crisis and Resistance. Winnipeg: Fernwood.isEp:

Menzigian, Katrina, Skand Bhargava, and Sharang Sharma. 2015. Contact Center Outsourcing Annual Report 2015: Incumbents Beware - There's no Place for Complacency. Everest Group. Accessed February 17, 2020. https://www.everestgrp.com/2015-06-contact- 
center-outsourcing-annual-report-2015-incumbents-beware-theres-no-place-for-complacency-market-insights-18078.html/

Meoño Artiga, L. P. 2016. Transnational "Homies" and the Urban Middle Class: Enactments of Class, Nation, and Modernity in Guatemalan Call Centres. In Borders in Service. Enactments of Nationhood in Transnational Call Centres, edited by Kiran Mirchandani and Winifred Poster, 152-178. Toronto: Toronto University Press.

Mezzadra, Sandro, and Brett Neilson. 2013. Border as Method, or, the Multiplication of Labor. Durham, NC: Duke University Press.

Micheli, Jordy. 2012. El Sector de Call Centers: Estructura y Tendencias. Apuntes Sobre la Situación de México. Frontera Norte 24 (47): 145-169.

Mirchandani, Kiran. 2012. Phone Clones: Authenticity Work in the Transnational Service Economy. Ithaca, NY: ILR Press.

Mirchandani, Kiran, and Winifred R. Poster, eds. 2016. Borders in Service: Enactments of Nationhood in Transnational Call Centre. Toronto: University of Toronto Press.

Murphy, Pat. 2018. Personal communication, April 26.

Patel, Reena. 2010. Working the Night Shift: Women in India's Call Center Industry. Stanford: Stanford University Press.

Poloz, Stephen S. 2018. Canada's Economy and Household Debt - How Big is the Problem? Bank for International Settlements, May 1. Accessed February 17, 2020. https://www.bis.org/review/r180503a.htm

Poster, Winifred R. 2013. Hidden Sides of the Debt Economy: Emotions, Outsourcing, and Indian Call Centers. International Journal of Comparative Sociology 54 (3): 205-227.

Poster, Winifred R. 2007. Who's on the Line? Indian Call Center Agents Pose as Americans for US-outsourced Firms. Industrial Relations 46 (2): 271-304.

Qiu, Jack L. 2010. Network Labour and Non-Elite Knowledge Workers in China. Work Organisation, Labour \& Globalisation 4 (2): 80-95.

Rae, Alasdair and Garrett Dash Nelson. 2017. The Geography of the American Commute. In Big Data for Regional Science, edited by Laurie A. Schintler and Zhenhua Chen. London: Routledge.

Robinson, Cedric. 1983/2000. Black Marxism: The Making of the Black Radical Tradition. Chapel Hill: University of North Carolina Press.

Robinson, William. 2018. Accumulation Crisis and Global Police State. Critical Sociology 45 (6): 1-14. https://doi.org/10.1177/0896920518757054

Rock, Paul. 1973. Making People Pay. London: Routledge \& Kegan Paul.

Ross, Andrew. 2014. Creditocracy and the Case for Debt Refusal. New York: OR Books.

Schiller, Dan. 2014. Digital Depression: Information Technology and Economic Crisis. Urbana: University of Illinois Press.

Schiller, Dan. 1999. Digital Capitalism: Networking the Global Market System. Cambridge, MA: MIT Press.

Scott, James C. 1990. Domination and the Arts of Resistance: Hidden Transcripts. New Haven: Yale University Press.

Sinha, Anita. 2015. Slavery by Another Name: 'Voluntary' Immigrant Detainee Labor and the Thirteenth Amendment. Stanford Journal of Civil Rights \& Civil Liberties 11 (1): 1-44.

Sobol, Neil L. 2016. Charging the Poor: Criminal Justice Debt \& Modern-Day Debtors' Prisons. Maryland Law Review 75 (2): 486-540.

Soederberg, Susanne. 2014. Debtfare States and the Poverty Industry: Money, Discipline and the Surplus Population. London: Routledge.

Taylor, Phil, and Peter Bain. 2008. United by a common language? Trade union responses in the UK and India to call centre offshoring. Antipode 40 (1): 131-154.

United States Department of Justice. 2017. Federal Justice Statistics 2013-2014. Accessed July 16, 2019. https://www.bjs.gov/content/pub/pdf/fjs1314.pdf

United States Immigration and Customs Enforcement. 2017. ICE ERO Immigration Arrests Climb Nearly 40\%. Accessed July 16, 2019. https://www.ice.gov/features/100-days 
Wang, Jackie. 2018. Carceral Capitalism. South Pasadena: Semiotext(e).

Wessler, Seth Freed. 2014. Call centers: Returning to Mexico but sounding 'American'. AlJazeera America. Aljazeera, March 16. Accessed February 17, 2020. http://america.aljazeera.com/features/2014/3/mexico-s-call-centers.html

Woodman, Spencer. 2017. Exclusive: ICE put Detained Immigrants in Solitary Confinement for Hunger Striking. The Verge, February 27. Accessed February 17, 2020. https://www.theverge.com/2017/2/27/14728978/immigrant-deportation-hunger-strike-solitary-confinement-ice-trump

\section{About the Authors}

Enda Brophy

Enda Brophy is an Associate Professor in the School of Communication and an Associate in Labour Studies at Simon Fraser University. He is the author of Language Put to Work: The Making of the Global Call Centre Workforce, which won book of the year awards from the Canadian Association of Work and Labour Studies and the Canadian Communication Association in 2018.

\section{Rodrigo Finkelstein}

Rodrigo Finkelstein is a PhD candidate in the School of Communication at Simon Fraser University. He is the author of Riesgos Laborales: Una Visión Cultural [Labour Risks: A Cultural View] (2018). His research interests include Marxian political economy, the political economy of communication, and health information at work. 